John M. Baratta, MD

P. James B. Dyck, MD

Patricio Brand, MD

Pariwat Thaisetthawatkul, MD

Peter J. Dyck, MD

JaNean K. Engelstad, HT

Brent Goodman, MD

Chafic Karam, MD

Correspondence to

Dr. Karam:

chafickaram@gmail.com

\title{
Vasculitic neuropathy following exposure to minocycline
}

\section{OPEN}

\section{ABSTRACT}

Objective: To report 3 patients with minocycline-induced autoimmunity resulting in peripheral nerve vasculitis.

Methods: We report 3 patients who, during minocycline treatment for acne vulgaris, developed subacute onset of pain and weakness caused by vasculitis in single and multiple mononeuropathy patterns.

Results: Each patient underwent either a nerve or muscle biopsy that confirmed vasculitis. One patient additionally developed systemic symptoms (including fever, fatigue, and night sweats) and another had a posterior circulation stroke. Symptoms developed with either early or prolonged use of minocycline. Despite withdrawal of minocycline, patients needed long-term immunotherapy to gain neurologic improvement.

Conclusions: Our findings suggest that the typical neuropathy associated with minocycline use is painful single or multiple mononeuropathy due to peripheral nerve vasculitis, which may also be accompanied by presumed CNS vasculitis (presenting as stroke). Neurol Neuroimmunol Neuroinflamm 2016;3:e180; doi: 10.1212/NXI.0000000000000180

\section{GLOSSARY}

ANA $=$ antinuclear antibody.

Minocycline is a synthetic tetracycline derivative commonly used for its broad-spectrum antibiotic properties, such as in the treatment of acne vulgaris. Prior reports have demonstrated an association between minocycline exposure and development of autoimmune syndromes, such as serum sickness, drug-induced lupus, autoimmune hepatitis, and systemic vasculitis. ${ }^{1}$ There are additionally several previously reported cases of minocycline-associated vasculitic neuropathy as part of a systemic, drug-induced, lupus-like, ${ }^{2}$ or polyarteritis nodosa-like syndrome. ${ }^{3}$ In this case series, we describe 3 patients, 1 previously reported, ${ }^{4}$ who developed a stereotypical syndrome of painful single or multiple mononeuropathy following minocycline exposure. These conditions were sometimes associated with systemic symptoms (such as fevers and night sweats) and with posterior circulation strokes.

CASE REPORTS Patient 1. A 17-year-old otherwise healthy girl awoke with new-onset arm pain, numbness, and weakness in the left ulnar nerve distribution. She had a history of acne for which she had taken minocycline for 3 years. Eleven days after development of the left arm symptoms, she developed numbness over the lateral aspects of the bilateral feet and thighs.

She was seen by an orthopedist who believed she had a compressive left ulnar neuropathy at the elbow and, on day 31 after symptom onset, she underwent a left ulnar nerve transposition. Left arm pain and weakness worsened postoperatively. A month later, the patient developed acute left leg weakness, nausea, and vertigo,

From the Departments of Physical Medicine \& Rehabilitation (J.M.B.) and Neurology (C.K.), The University of North Carolina, Chapel Hill; the Department of Neurology (P.J.B.D., P.B., P.J.D., J.K.E.), Mayo Clinic, Rochester, MN; the Department of Neurological Sciences (P.T.), University of Nebraska Medical Center, Omaha; and the Department of Neurology (B.G.), Mayo Clinic, Scottsdale, AZ.

Funding information and disclosures are provided at the end of the article. Go to Neurology.org/nn for full disclosure forms. The Article Processing Charge was paid by UNC Neurology.

This is an open access article distributed under the terms of the Creative Commons Attribution-NonCommercial-NoDerivatives License 4.0 (CC BY-NC-ND), which permits downloading and sharing the work provided it is properly cited. The work cannot be changed in any way or used commercially. 
which prevented her from walking. On examination, she demonstrated left arm and bilateral ankle dorsiflexion weakness and reduced sensation in the left hand and bilateral feet.

Subsequent brain MRI showed an acute right medial medullary ischemic stroke. Extensive evaluation did not reveal a hypercoagulable state, embolic source, or large artery abnormality. Nerve conduction studies and needle EMG showed diffuse abnormalities within all limbs, which were asymmetric and suggestive of an axonal multiple mononeuropathy or asymmetrical polyradiculoneuropathy. Left upper extremity findings localized to the brachial plexus or multiple peripheral nerves. A brachial plexus MRI showed generalized increased T2 signal intensity throughout the course the left brachial plexus. Antinuclear antibody (ANA) was mildly positive (1:160) and C-reactive protein was elevated (18.4). CSF analysis was normal. Autoimmune and infectious workups were otherwise negative. A left superficial radial nerve biopsy was consistent with necrotizing vasculitis (figure 1).

Following diagnosis, minocycline was discontinued. The patient was started on IV methylprednisolone and azathioprine. On follow-up several months

\section{Figure 1 Patient 1 radial nerve biopsy}

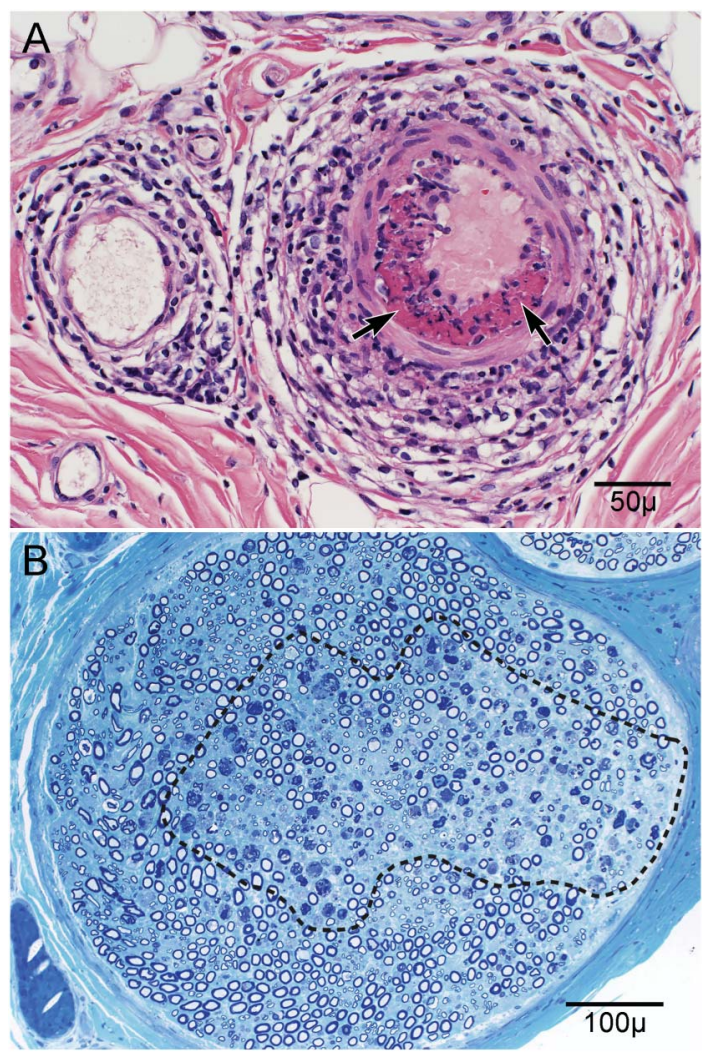

(A) Hematoxylin \& eosin stain of radial nerve demonstrates epineurial nerve large arteriole necrotizing vasculitis. Note the prominent inflammatory cell infiltrate infiltrating and disrupting all layers of the arteriolar wall and the fibrinoid necrosis (arrows). (B) Methylene blue stain of radial nerve demonstrates myelinated fiber degeneration in the center of the fascicle that is typical of ischemic changes (outlined). after discharge, she demonstrated good clinical improvement with regard to pain, strength, and sensation.

Patient 2. A 33-year-old man was seen in consultation for evaluation of left foot pain and weakness. The patient had a several month history of recurrent episodes of generalized muscle soreness, joint pain, and fatigue. Episodes would last up to several days at a time. The most severe episode occurred in conjunction with a fever $\left(103^{\circ} \mathrm{F}\right)$, chills, cold sweats, low back pain radiating to the right testicle, and acute left leg and foot pain and paresthesias. He had been taking minocycline for acne for 2 years. Strength examination was normal apart from mild left foot inversion, ankle plantarflexion, and toe weakness. There was reduced sensation to vibration at the left toe and reduced pinprick at the sole of the left foot.

An ANA was mildly positive (1:160) and a thyroid peroxidase antibody level was elevated (19.34). Autoimmune and infectious workups were otherwise negative. No imaging was performed. Electrophysiology studies demonstrated an isolated left, subacute, primarily axonal, tibial mononeuropathy. A left gastrocnemius muscle biopsy was consistent with necrotizing vasculitis (figure 2).

Following diagnosis, the minocycline was discontinued. The patient was initiated on high-dose oral prednisone and IV cyclophosphamide. At 3-month follow-up after diagnosis, he demonstrated clinical improvement of strength and pain. His constitutional symptoms had fully resolved.

Patient 3 (previously reported). A 28-year-old woman presented for evaluation of weakness, pain, and paresthesia in the left foot. ${ }^{4}$ She was previously healthy other than starting minocycline 2 weeks prior for treatment of acne vulgaris. Minocycline was discontinued shortly after symptom onset.

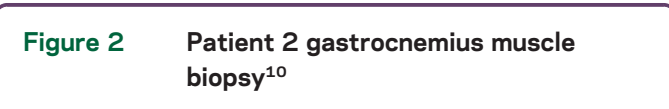

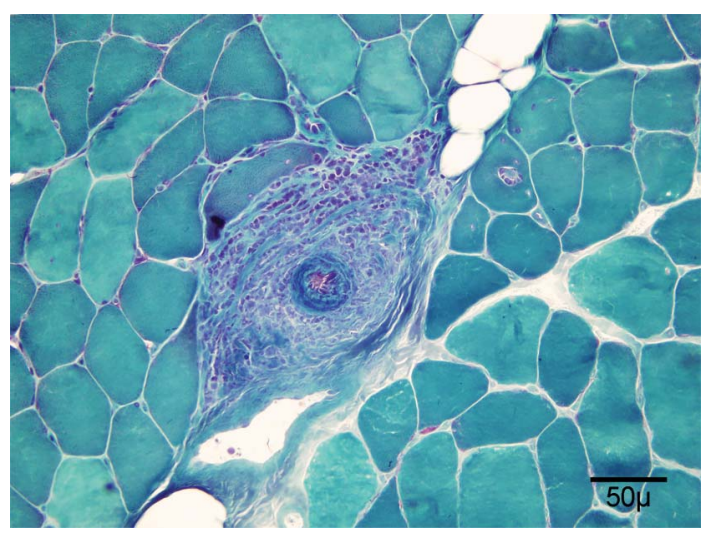

Gomori trichrome stain of gastrocnemius muscle biopsy shows large arteriole necrotizing vasculitis. 
On examination, there was distal left foot weakness involving both peroneal and tibial distributions and diminished sensation in the left sciatic territory. Electrophysiology studies demonstrated a left sciatic mononeuropathy with active denervation in both peroneal and tibial innervated muscles. Serologic testing demonstrated positive ANA and SSA. The remainder of autoimmune and infectious workups was negative. A lumbosacral plexus MRI demonstrated mild increased T2 hyperintensity of the bilateral L4-S1 nerve roots with extension into the femoral and sciatic nerves. A left sural nerve biopsy was consistent with necrotizing vasculitis, with multifocal myelinated fiber loss as well as large and small perivascular inflammatory cell collections in both the endoneurium and epineurium.

After cessation of minocycline, the patient was started on a $1 \mathrm{~g}$ per week 12-week IV methylprednisolone treatment session. She was seen in follow-up at 3 months, by which time her strength and gait had returned to normal.

DISCUSSION Minocycline exposure has recently been associated with the development of several types of systemic autoimmune syndromes. ${ }^{1-3}$ Our 3 cases further demonstrate an association between minocycline exposure and development of both systemic (patient 2, who presented with constitutional symptoms) and possible nonsystemic (patients 1 and 3) vasculitic neuropathies. In each of the 3 cases presented above, minocycline had been initiated for treatment of acne vulgaris before the onset of the neuropathy. The diagnosis of single or multiple vasculitic mononeuropathy in each case was confirmed by nerve or muscle biopsy.

There have also been reports of 2 cases of posterior circulation stroke $e^{5,6}$ and one case of cervical myelopathy in association with vertebral artery vasculitis ${ }^{7}$ secondary to polyarteritis nodosa-like syndrome related to minocycline use. Patient 1 , who sustained an acute right medial medullary ischemic stroke, had no traditional cerebrovascular risk factors and extensive evaluation did not reveal any embolic source or large artery abnormality. Given that the rest of her illness was due to peripheral nerve vasculitis, this patient's stroke was likely due to CNS vasculitis.

The current understanding of minocyclineinduced autoimmunity suggests that haptens, which invoke the immune response, may be the product of minocycline processing by neutrophils or hepatocytes. ${ }^{8}$ Haptens may further bind to degrading enzymes inducing an immune response against those enzymes, such as anti-myeloperoxidase antibodies. Of note, antihistone antibody, which is present in more than $95 \%$ of traditional drug-induced lupus, is frequently absent in minocycline-induced autoimmune syndromes. ${ }^{8}$ The reason for this is unclear.
The timing of minocycline initiation and development of symptoms was variable, ranging from acute $(2$ weeks in patient 4 ) to chronic exposures (2-4 years in patients 1-3). Prior reports of systemic minocyclineinduced lupus suggest that autoimmunity typically develops after chronic administration of the drug, with Schlienger et al. ${ }^{9}$ suggesting a median time to onset of 19 months.

Patients who develop a minocycline-induced autoimmune condition typically respond to cessation of the minocycline with administration of oral or IV corticosteroids. ${ }^{8}$ A steroid-sparing agent, such as cyclophosphamide or azathioprine, may also be added. All 3 of our patients demonstrated clinical improvement following cessation of minocycline and initiation of glucocorticoids with a steroid-sparing agent.

This case series adds to the growing body of literature regarding minocycline-induced autoimmunity. Each of our cases presented in a stereotypical way with the development of pain and weakness in the distribution of single or multiple individual nerves and showed evidence of ischemic injury and vasculitis on nerve and muscle biopsy. One of the patients had a simultaneous posterior circulation stroke. Physicians treating those with neuromuscular conditions should be aware of the possible association between minocycline exposure and the development of both nonsystemic and systemic vasculitic neuropathies and cerebral posterior circulation strokes.

\section{AUTHOR CONTRIBUTIONS}

John M. Baratta: conceptualization, data interpretation, manuscript drafting and revision. P. James B. Dyck: conceptualization, data interpretation, manuscript drafting and revision. Patricio Brand: conceptualization, data interpretation. Pariwat Thaisetthawatkul: conceptualization, data interpretation, manuscript drafting and revision. Peter J. Dyck: conceptualization, data interpretation, manuscript drafting and revision. JaNean K. Engelstad: data interpretation. Brent Goodman: conceptualization, data interpretation. Chafic Karam: conceptualization, data interpretation, manuscript drafting and revision.

\section{STUDY FUNDING}

No targeted funding.

\section{DISCLOSURE}

J.M. Baratta reports no disclosures. P.J.B. Dyck is an associate editor for Journal of Neurology, Neurosurgery and Psychiatry. P. Brand and P. Thiasetthawatkul report no disclosures. P.J. Dyck was an associate editor for Diabetes, and received research support from Pfizer, Isis Pharmaceuticals, Anylam Pharmaceuticals, NIH, FDA, and NCRR. JaNean Englestad received royalties from Saunders. B.P. Goodman reports no disclosures. C. Karam serves as Neurology ${ }^{\circledR}$ WriteClick ${ }^{\circledR}$ deputy editor, was on the editorial board for Neurology Resident and Fellow Section, received speaker honoraria from NuFACTOR, and has consulted for Lundbeck. Go to Neurology.org/nn for full disclosure forms.

Received June 19, 2015. Accepted in final form October 6, 2015.

\section{REFERENCES}

1. Elkayam O, Yaron M, Caspi D. Minocycline-induced autoimmune syndromes: an overview. Semin Arthritis Rheum 1999;28:392-397. 
2. Graham L, Bell A. Minocycline-associated lupus-like syndrome with ulnar neuropathy and antiphospholipid antibody. Clin Rheumatol 2001;20:67-69.

3. Ogawa N, Kawai H, Yamakawa I, Sanada M, Sugimoto T, Maeda K. Case of minocycline-induced vasculitic neuropathy [in Japanese]. Rinsho Shinkeigaku 2010;50:301-305.

4. Thaisetthawatkul P, Sundell R, Robertson CE, Dyck PJ. Vasculitic neuropathy associated with minocycline use. J Clin Neuromuscul Dis 2011;12:231-234.

5. Kermani TA, Ham EK, Camilleri MJ, Warrington KJ. Polyarteritis nodosa-like vasculitis in association with minocycline use: a single-center case series. Semin Arthritis Rheum 2012;42:213-221.

6. Klaas JP, Matzke T, Makol A, Fulgham JR. Minocyclineinduced polyarteritis nodosa-like vasculitis presenting as brainstem stroke. J Clin Neurosci 2015;22: 904-907.

7. Garg N, Altowaijri GH, Nesbit GM, Gultekin SH, Bourdette DN. Minocycline-associated vasculitis of extracranial branches of vertebral arteries presenting as myelopathy. Neurol Neuroimmunol Neuroinflamm 2014;1:e7.

8. Schaffer JV, Davidson DM, McNiff JM, Bolognia JL. Perinuclear antineutrophilic cytoplasmic antibody-positive cutaneous polyarteritis nodosa associated with minocycline therapy for acne vulgaris. J Am Acad Dermatol 2001;44: 198-206.

9. Schlienger RG, Bircher AJ, Meier CR. Minocyclineinduced lupus. A systematic review. Dermatology 2000; 200:223-231.

10. Karam C. Eye of the storm. Neurology 2015;84:1180. 


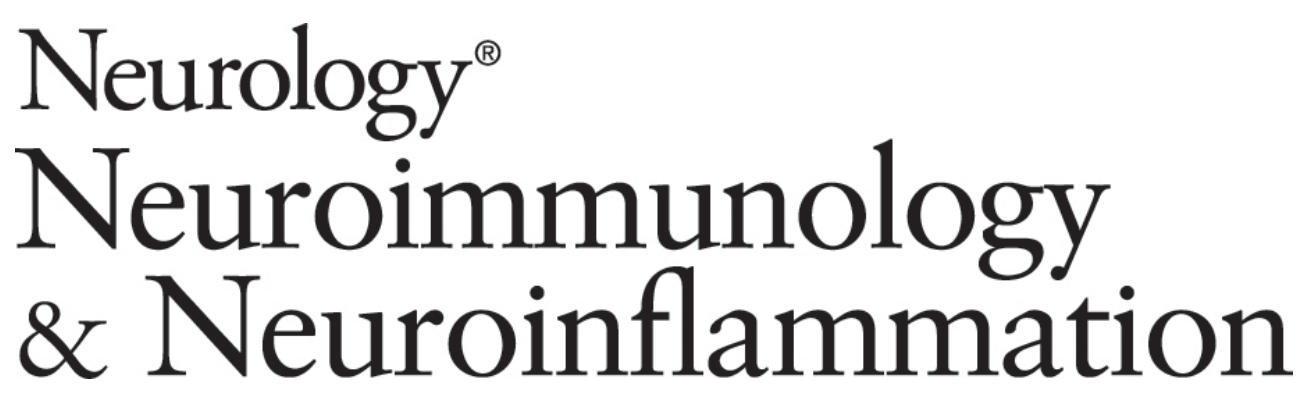

Vasculitic neuropathy following exposure to minocycline

John M. Baratta, P. James B. Dyck, Patricio Brand, et al.

Neurol Neuroimmunol Neuroinflamm 2016;3;

DOI 10.1212/NXI.0000000000000180

This information is current as of November 12, 2015

Neurol Neuroimmunol Neuroinflamm is an official journal of the American Academy of Neurology.

Published since April 2014, it is an open-access, online-only, continuous publication journal. Copyright $\odot$ 2015 American Academy of Neurology. All rights reserved. Online ISSN: 2332-7812.

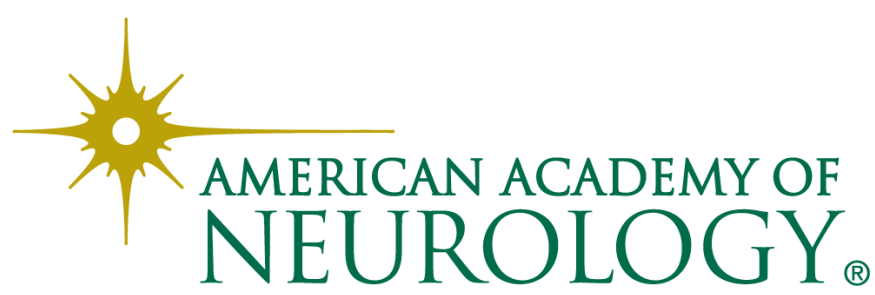




\section{Updated Information \& Services}

\section{Supplementary Material}

\section{References}

Subspecialty Collections

Permissions \& Licensing

\section{Reprints}

including high resolution figures, can be found at:

http://nn.neurology.org/content/3/1/e180.full.html

Supplementary material can be found at:

http://nn.neurology.org/content/suppl/2016/02/15/3.1.e180.DC1

This article cites 10 articles, 0 of which you can access for free at: http://nn.neurology.org/content/3/1/e180.full.html\#\#ref-list-1

This article, along with others on similar topics, appears in the following collection(s):

\section{All Cerebrovascular disease/Stroke}

http://nn.neurology.org//cgi/collection/all_cerebrovascular_disease_str oke

All Immunology

http://nn.neurology.org//cgi/collection/all_immunology

Autoimmune diseases

http://nn.neurology.org//cgi/collection/autoimmune_diseases

Other cerebrovascular disease/ Stroke

http://nn.neurology.org//cgi/collection/other_cerebrovascular_disease stroke

Vasculitis

http://nn.neurology.org//cgi/collection/vasculitis

Information about reproducing this article in parts (figures,tables) or in its entirety can be found online at:

http://nn.neurology.org/misc/about.xhtml\#permissions

Information about ordering reprints can be found online: http://nn.neurology.org/misc/addir.xhtml\#reprintsus

Neurol Neuroimmunol Neuroinflamm is an official journal of the American Academy of Neurology.

Published since April 2014, it is an open-access, online-only, continuous publication journal. Copyright $\odot$ 2015 American Academy of Neurology. All rights reserved. Online ISSN: 2332-7812.

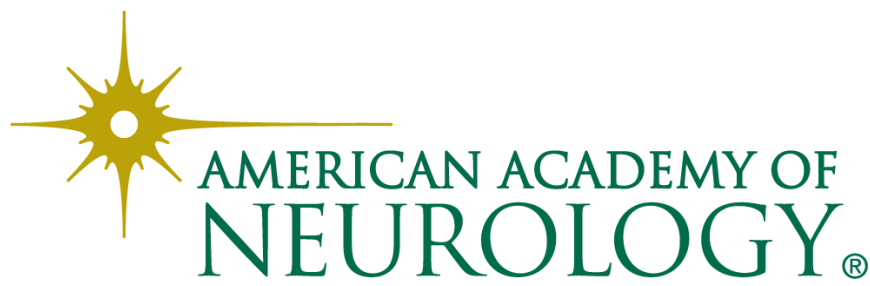

